\title{
Photoinduced Electron Transfer Reactions of Aryl Benzyl Sulfides Promoted by 2,4,6-Triphenylpyrilium Tetrafluoroborate $\left(\mathrm{TP}^{+} \mathrm{BF}_{4}^{-}\right)$
}

\author{
Hamid Reza Memarian, ${ }^{*}$ Iraj Mohammadpoor-Baltork, and Kiumars Bahrami \\ Faculty of Science, Department of Chemistry, University of Isfahan, Isfahan 81746-73441, Iran \\ "E-mail: memarian@sciuiac.ir \\ Received Angust 1, 2005
}

\begin{abstract}
Photocatalytic electron transfer reactions of aryl benzyl sulfides using 2,4,6-triphenylpyrilium tetrafluoroborate ( $\mathrm{TP}^{\prime} \mathrm{BF}_{4}{ }^{-}$) resulted in the oxidation of these sulfides to the corresponding sulfoxides and also in most cases in the C-S bond cleavage of them along with formation of aromatic aldehydes. In these reactions, the formation of sultide radical cation has been proposed, which undergoes either oxidation to the corresponding sulfoxide or C-S bond cleavage to the formation of aromatic aldehydes. The further oxidation of sulfoxides to sulfones has not been observed. The influence of substrate structures on the reaction pathways as well as the role of $\mathrm{O}_{2}$ in this respect is discussed.
\end{abstract}

Key Words : Electron transfer, Aryl benzyl sulfides, Sulfoxides, Photocleavage, Photochemistry

\section{Introduction}

Photooxidation of organic sulfides has been extensively studied and is still under investigation. This reaction has received extensive study under a variety of reaction conditions, namely, I) autooxidation, ${ }^{1-4}$ II) electron transfer sensitization $^{5-12}$ and III) singlet oxygen oxidation. ${ }^{13-22}$ A mechanism involving radical cation intermediates of sulfides was proposed for the electron transfer sensitized reactions using titanium dioxide ${ }^{6.8}$ 2,4,6-tri(p-chlorophenyl)pyrilium perchlorate (TCPPClO 4$), 79,10$-dicyanoanthracene ${ }^{7.9-12}$ and $N$-methylquinolinium tetrafluoroborate, ${ }^{12}$ but none of these works has reported the results of the photoreaction of various organic sulfides to elucidate the type of the aryl group on the extent of C-S bond cleavage ws. S-oxidation like our present work.

Photoinduced electron transfer (PET) processes have attracted growing interest in the last decade and many reactions such as cycloadditions, cycloreversions, oxygenations and fragmentations have been documented. ${ }^{23-28}$

2,4,6-Triphenylpyrylium tetrafluoroborate $\left(\mathrm{TP}^{\prime} \mathrm{BF}_{+}^{-}\right)$absorbs in the visible region and is a strong oxidizing agent in the excited state. The advantage of the use of this compound as a PET-sensitizer is its high solubility in many organic solvents and due to its salty character $\left(\mathrm{TP}^{\prime} \mathrm{BF}_{4}^{-}\right)$, no net charge separation is needed for the electron transfer step, since pyrilium ring accept the electron, which is already separated from its counter ion, namely $\mathrm{BF}_{4}^{-}$. This leads to enhancement of the formation of free radical cation from donor molecule because of reduced back electron transfer. The result is an increase of the efficiency of quantum yield of PET-reactions.

Recently, we have reported on photoinduced electron transfer ring opening of a-epoxyketones using 2,4,6-triphenylpyrilium tetrafluoroborate $\left(\mathrm{TP}^{\prime} \mathrm{BF}_{4}^{-}\right)$as photocatalyst in methanol, ${ }^{29}$ acetone, ${ }^{30}$ cyclohexanone ${ }^{31}$ and acetic acid solutions. ${ }^{32}$ We found out that $\mathrm{TP}^{\prime} \mathrm{BF}_{4}^{-}$is a powerful photoelectron acceptor compared with $\mathrm{TiO}_{2}{ }^{33}$ and $7,7,8,8-$ tetracyano-p-quinodimethane (TCNQ). ${ }^{34}$

Now we wish to introduce the results of our investigation on the photoinduced oxidation of aryl benzyl sulfides with $\mathrm{TP}^{\prime} \mathrm{BF}_{4}^{-}$.

\section{Results and Discussion}

In a typical reaction, an oxygenated solution of sulfide (1 $\mathrm{mmol})$ and $\mathrm{TP}^{\prime} \mathrm{BF}_{4}^{-}(0.05 \mathrm{mmol})$ in acetonitrile was irradiated for the time given in Table 1 . The progress of the reaction was followed by TLC and irradiation has been continued until total disappearance of the sulfides (Scheme 1). The results are summarized in Table 1.

Regarding to result from the control experiments and the results presented in Table 1 we found out that:

1. The presence of photocatalyst $\mathrm{TP}^{\prime} \mathrm{BF}_{+}^{-}$is necessary for the reaction, because irradiation of 1 a without $\mathrm{TP}^{\prime} \mathrm{BF}_{4}{ }^{-}$as a test experiment does not result in the occurrence of any reactions.

2. The formation of the observed products by direct excitation of sulfides is ruled out, since the light has been passed through a filter solution to cut-off the UV light which might be absorbed by the sulfides.

3. The presence of oxygen is necessary for the reaction, since no products have been observed to be generated on irradiation of $1 \mathrm{a}$ and $\mathrm{TP}^{\prime} \mathrm{BF}_{4}{ }^{-}$under argon atmosphere.

4. Two types of reactions, oxidation of sulfides to the corresponding sulfoxides and C-S bond cleavage and consequently formation of arylaldehydes have been observed.

On the basis of the foregoing results, the following mechanism is proposed for the reaction (Scheme 2):

According to the proposed mechanism, a photoinduced electron transfer from sulfide to the excited photocatalyst $\mathrm{TP}^{\prime} \mathrm{BF}_{4}^{-}$leads to the formation of sulfide radical cation 6 . In the case of benzyl sulfides 1a-1k, deprotonation of 6 and formation of $\alpha$-thiophenoxy carbon radical 7 is the 


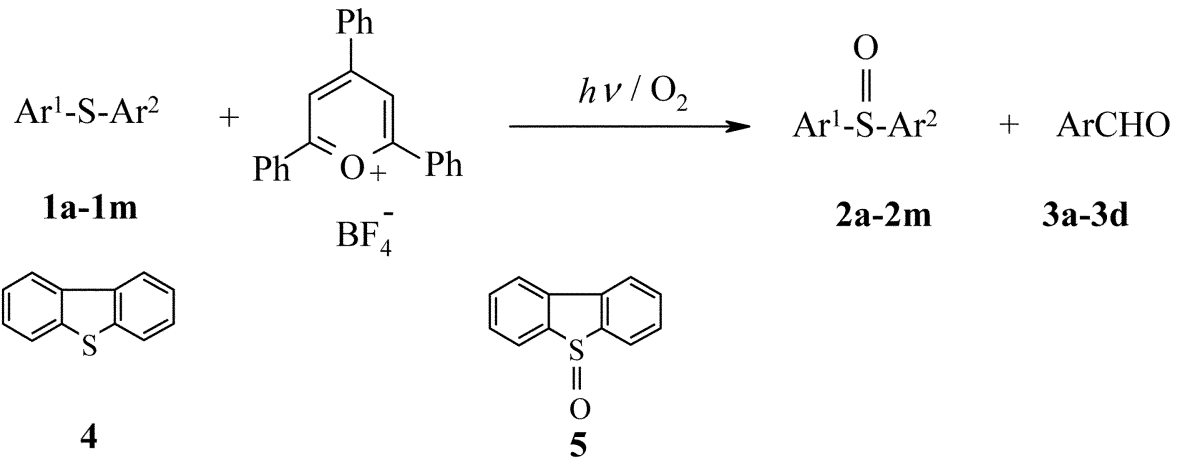

Scheme 1

Table 1. Products of photoclectron transfer reactions of sulfides by $\mathrm{TP}^{-} \mathrm{BF}_{4}^{-1}$

\begin{tabular}{|c|c|c|c|c|c|}
\hline \multirow{2}{*}{ Comp. } & \multirow{2}{*}{$\mathrm{Ar}^{\prime}$} & \multirow{2}{*}{$\mathrm{Ar}^{2}$} & Product & $(\% \text { YYield })^{1111.1 \mathrm{~N}}$ & \multirow{2}{*}{ Timin' } \\
\hline & & & Sulfoxide & Aldehyde/Ar & \\
\hline Ia & $\mathrm{C}_{6} \mathrm{H}_{5}$ & $\mathrm{C}_{n} \mathrm{H}_{3} \mathrm{Cl}_{2}$ & $2 a(14)$ & $3 a, \mathrm{C}_{5} \mathrm{H}_{5}(38)$ & 120 \\
\hline $1 b$ & $\mathrm{C}_{6} \mathrm{H}_{3}$ & $p-\mathrm{BrC}_{6} \mathrm{H}_{1} \mathrm{CH}_{2}$ & $2 b(15)$ & $3 \mathbf{b}, p-\mathrm{BrC}_{6} \mathrm{H}_{4}(40)$ & 60 \\
\hline lc & $\mathrm{C}_{6} \mathrm{II}_{5}$ & $p-\mathrm{CH}_{3} \mathrm{C}_{6} \mathrm{ll}_{4} \mathrm{CH}_{2}$ & $2 c(3)$ & 3c, $p-\mathrm{CH}_{3} \mathrm{C}_{n} \mathrm{ll}_{1}(43)$ & 40 \\
\hline 1d & $\mathrm{C}_{\mathrm{ft}} \mathrm{Il}_{5}$ & $p-\mathrm{NO}_{2} \mathrm{C}_{62} \mathrm{I}_{4} \mathrm{ClI}_{2}$ & $2 d(3)$ & 3d, $p-\mathrm{NO}_{2} \mathrm{C}_{6} \mathrm{Il}_{+}(46)$ & 50 \\
\hline le & $p-\mathrm{CII}_{3} \mathrm{C}_{6} \mathrm{I}_{4}$ & $\mathrm{C}_{0} \mathrm{ll} \mathrm{C}$ & $2 \mathrm{e}(15)$ & $3 a, C, I_{5}(40)$ & 60 \\
\hline If & $p-\mathrm{CI}_{2} \mathrm{C}_{6} \mathrm{IL}_{4}$ & $p-\mathrm{BrC}_{4} \mathrm{~J}_{4} \mathrm{CII}_{2}$ & $2 f(15)$ & $3 \mathbf{b}, p-\mathrm{BrC}_{4 \mathrm{l}} \mathrm{H}_{4}(4 \mathrm{l})$ & 65 \\
\hline $1 \mathrm{~g}$ & $p-\mathrm{ClC}_{6} \mathrm{H}_{4}$ & $\mathrm{C}_{6} \mathrm{I}_{5} \mathrm{Cl}_{2}$ & $\lg (16)$ & $\mathbf{3 a}, \mathrm{C}_{6} \mathrm{II}_{5}(38)$ & 70 \\
\hline ih & $p-\mathrm{ClC}_{6} \mathrm{H}_{4}$ & $\left.p-\mathrm{BrC}_{\mathrm{k}_{1}}\right] \mathrm{L}_{4} \mathrm{Cl}_{2}$ & $2 h(16)$ & $3 \mathbf{b}, p-\mathrm{BrC}_{4} \mathrm{H}_{4}(39)$ & 70 \\
\hline $\mathrm{li}$ & $p-\mathrm{ClC}_{6} \mathrm{H}_{4}$ & $p-\mathrm{NO}_{2} \mathrm{C}_{6}, \mathrm{H}_{4} \mathrm{CH}_{2}$ & $2 \mathrm{i}(6)$ & 3d. $p$ - $\mathrm{NO}_{2} \mathrm{C}_{6} \mathrm{H}_{4}(44)$ & 55 \\
\hline \multirow[t]{2}{*}{$\mathbf{1 j}$} & $\mathrm{C}_{6} \mathrm{H}_{3} \mathrm{CH}_{2}$ & $p-\mathrm{BrC}_{41} \mathrm{H}_{1} \mathrm{CH}_{2}$ & $2 \mathbf{j}(14)$ & $3 a, C_{6} H_{5}(10)$ & 150 \\
\hline & & & & 3b. $p-\mathrm{BrC}_{0} \mathrm{H}_{4}(30)$ & \\
\hline $1 \mathbf{k}$ & $\mathrm{C}_{0} \mathrm{H}_{3} \mathrm{CH}_{2}$ & $\mathrm{C}_{6} \mathrm{H}_{5} \mathrm{CH}_{2}$ & $2 \mathrm{k}(15)$ & $3 a, C_{0} H_{5}(37)$ & 170 \\
\hline 11 & $\mathrm{C}_{b_{3}} \mathrm{H}_{3}$ & $\mathrm{C}_{n} \mathrm{H}_{s}$ & $21(93)$ & & 300 \\
\hline Im & 2-pyridyl & $2,4-\left(\mathrm{NO}_{2}\right)_{2} \mathrm{C}_{6} \mathrm{H}_{3}$ & $2 \mathrm{~m}(0)$ & & 300 \\
\hline 4 & & & $5(95)$ & & 300 \\
\hline
\end{tabular}

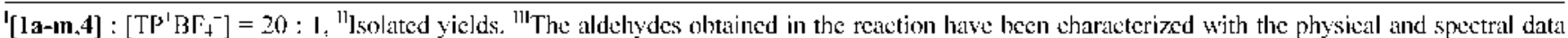
with those of authentic samples. "In the case of 1a-1k, arylsulfenic acids could not be isolated hy chromatography methods, therelore, the yjekt of these acids has not been delermined. "The times are givent for total conversion of the sullides.

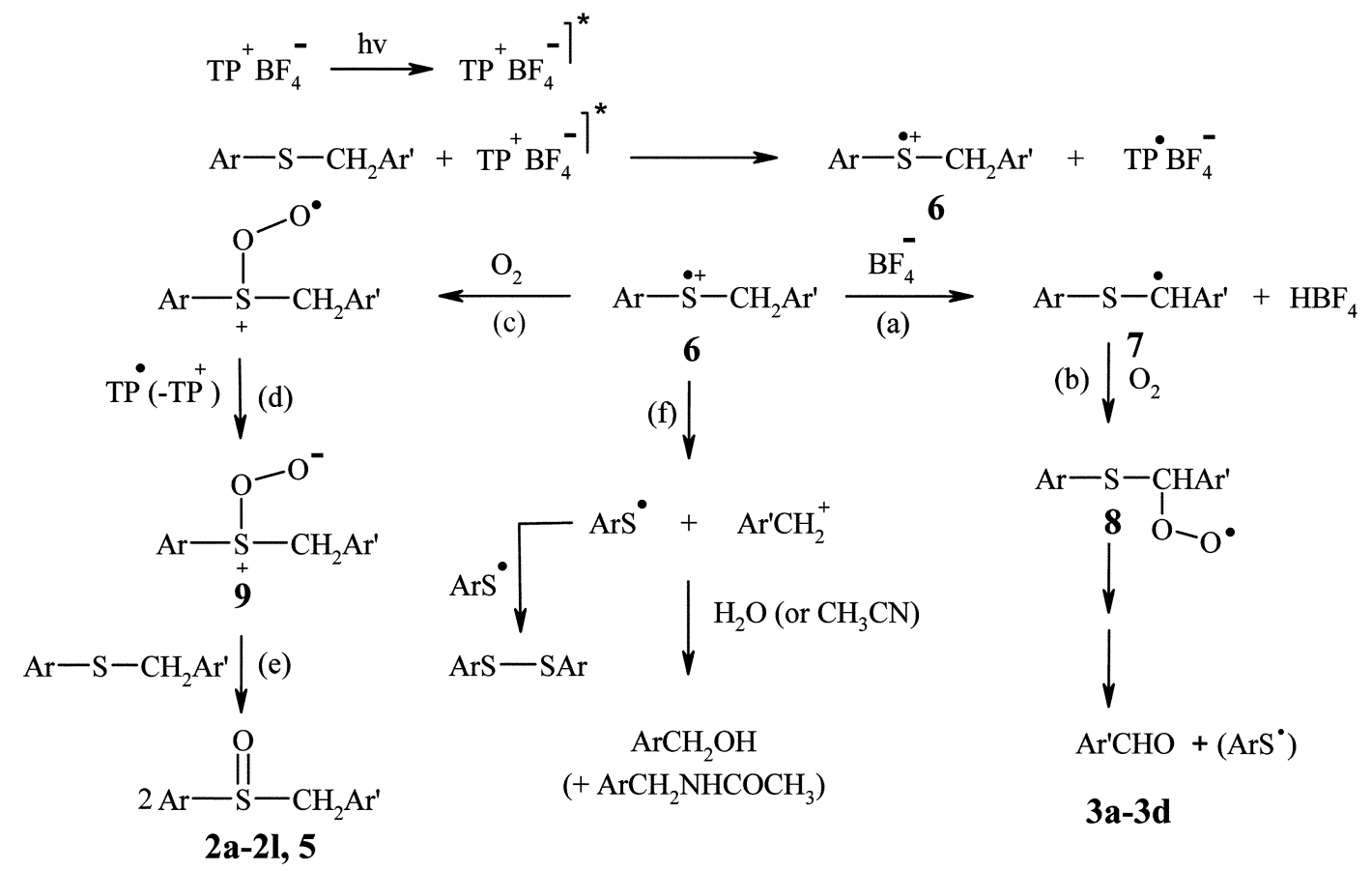

Scheme 2 
predominant path for the radical cation intermediate 6 and therefore arylaldehydes 3a-3d are formed as the major products accompanied by less amounts of sulfoxides $\mathbf{2 a - 2} \mathbf{k}$. In this reaction the intermediate 7 should react with $\mathrm{O}_{2}$ to give a peroxy radical 8 whose conversion to arylaldehydes 3al-3d has been shown. This suggestion is supported by the formation of the aldehydes, namely, benzaldehyde 3a and 4bromobenzaldehyde $\mathbf{3 b}$ from unsymmetrical benzylic sulfide $\mathbf{1 j}$ through the paths.

Oxidative cleavage of carbon-sulfur bond during reactions of alkyl benzyl sulfides with singlet oxygen using Tetraphenylporphyrin-Zn complex as sensitizer was first reported by Corey et $a l$. in $1976 .{ }^{35}$ Besides products deriving from C$\mathrm{S}$ bond cleavage, the formation of the corresponding sulfoxides and sulfones have also been observed during these reactions. According to the proposed mechanism for the C-S bond cleavage, the attack of singlet oxygen to sulfides leads to the formation of radical or ionic intermediate, which undergoes Pummerer rearrangement to the observed products, namely, sulfoxides, sulfones and aldehydes. ${ }^{36}$ Since $\mathrm{TP}^{+} \mathrm{BF}_{4}^{-}$is not able to participate in energy transfer from its excited state to ground state oxygen, ${ }^{37,38}$ therefore, the involvement of singlet oxygen in our reaction for the C-S bond cleavage is ruled out. As we expected, oxidative cleavage of carbon-sulfur bond from sulfide radical cation intermediate 6 in our reactions can be observed only in the case of sulfides 1a-1k with benzylic substituent. It should be noted that in this case, we have isolated the corresponding aldehyde 3a-3d as major product and we did not find any product derived from thienyl radical (RS') intermediate such as arylsulfinic and arylsulfonic acids. As it has been reported these acids should be normally formed from the $\mathrm{O}_{2}$ promoted oxidation of the sulfur containing species produced in the $\mathrm{C}-\mathrm{S}$ bond cleavage pathway (arylthyil radical and its dimerization products). ${ }^{39.10}$ The formation of these compounds have been reported on reaction of organic sulfur compounds with superoxide anion. ${ }^{40}$ The formation of benzenesulfonic acid by photoinduced electron transfer reactions of benzyl phenyl sulfides promoted by 9,10 -dicyanoanthracene has been reported, but the yield is not determined. ${ }^{9}$ It should be noted that decreased yields of the observed products in the cases of sulfides 1a-1k is due to arylsulfonic acid, which could not be isolated by the chromatography methods, and therefore, their yields are not able to be measured and listed in the Table 1.

The sulfoxide products are probably formed by reaction of radical cation intermediate 6 with $\mathrm{O}_{2}$, leading to the formation of a persulfoxide intermediate 9 that is presumably able to oxidize another sulfide molecule to sulfoxide. This reaction through the paths $\mathfrak{c}, d$ and e occurs exclusively in the cases of sulfides 11 and 4 , since they do not have an $\alpha$ hydrogen containing benzylic substituent and the C-S bond cleavage is not expected.

An interesting result in our reaction is the influence of substrate structure on the reaction pathways. Whereas diphenyl sulfide 11, 2,4-dinitrophenyl 2-pyridyl sulfide $\mathbf{1 m}$ and also dibenzothiophene 4 which do not have benzylic methylene group did not give the products derived from C-S bond cleavage, because of unstability of radical cation 6 with electron-withdrawing group $\left(-\mathrm{NO}_{2}\right)$ oxidation of $1 \mathrm{~m}$ to the corresponding sulfoxide $\mathbf{2} \mathbf{m}$ did not observe even after irradiation for $5 \mathrm{~h}$. And, path $\mathrm{f}$ does not occur in 1a-k. The effect of various substituents on the phenyl group of the benzyl moiety, bromine $\mathbf{1 b}$, methyl $\mathbf{1 c}$, and nitro groups 1d instead of hydrogen 1a, is not clear since the irradiation time for completion of reaction and also the yield of photocleavage is not varied too much from each other, but their presence compared with hydrogen decrease the irradiation time

The involvement of superoxide anion, $\mathrm{O}_{2}^{-}$, in the reaction with sulfide radical cation for the formation of sulfoxide has been reported using 9,10-dicyanoanthracene ${ }^{9.14}$ or titanium dioxide. ${ }^{6}$ In the case of $\mathrm{TP}^{+} \mathrm{BF}_{4}{ }^{-}$, which we used as photocatalyst in our reactions, formation of superoxide anion, $\mathrm{O}_{2}{ }^{-}$, is not possible since cyclic voltammetry studies of dicyanoanthracene and $\mathrm{TP}^{+} \mathrm{BF}_{4}^{-}$indicate that in contrast to dicyanoanthracene radical anion, triphenylpyryl radical TP is not able to transfer an electron to molecular oxygen under formation of superoxide anion $\mathrm{O}_{2}{ }^{-}$and triphenylpyryl cation $\mathrm{TP}^{+} .37 .38+11$

Finally, a noteworthy result in our reaction is that the possibility of further oxidation of initially formed sulfoxides to sulfones is ruled out, since we did not observe any trace of any sulfones even with the TLC of the authentic sulfones although sulfones are easily detected and isolated by chromatography methods. However the formation of sulfones by the photosensitized oxidation of sulfoxides has been reported using dicyanoanthracene and rose Bengal. ${ }^{10.14}$

The advantage of this catalyst is the use of lower molar ratio of catalyst:sulfide $(1: 20)$ in our reactions compared with dicyanoanthracene : sulfide $(1: 10)^{9}$ and dimethoxynaphthalene : sulfide $(1: 2)^{17}$ in photoinduced electron transfer reaction of sulfides and also the observed photocleavage of C-S bond. It should be noted that overoxidation of sulfoxides to corresponding sulfones has not been observed, whereas overoxidation of dibenzothiophene 4 to dibenzothiophene sulfone has been reported using dicyanoanthracene. ${ }^{10}$ Other sulfides, diphenyl sulfide $\mathbf{1 1}$ and dibenzothiophene $\mathbf{4}$ have been converted efficiently to the corresponding sulfoxides after irradiation for $5 \mathrm{~h}$, whereas Baciocchi et al have obtained only $10 \%$ of diphenyl sulfoxide 21 on irradiation of diphenyl sulfide 11 by using $\mathrm{TiO}_{2}$ in $\mathrm{CH}_{3} \mathrm{CN}$ in the presence of $\mathrm{Ag}_{2} \mathrm{SO}_{4}$ after irradiation for $4 \mathrm{~h}^{8}{ }^{8}$ It should also be noted that no reactions of the aryl benzyl sulfides has been observed using 7,7,8,8-tetracyano-p-quinodimethane (TCNQ) as a photocatalyst.

\section{Conclusion}

In conclusion, this work describes electron transfer induced photooxidation reaction of aryl benzyl sulfides to the corresponding sulfoxides and to the aromatic aldehydes through $\mathrm{C}-\mathrm{S}$ bond cleavage. 


\section{Experimental Section}

Melting points were determined on a Stuart Scientific SMP2 apparatus and are uncorrected. IR spectra were recorded on a Shimadzu apparatus IR 435. 'H NMR spectra were recorded on Bruker 200 and $500 \mathrm{MHz}$. Elemental analyses were carried out on CHNO-rapid Heraeus. Starting materials have been prepared according to the known procedures ${ }^{+2,43}$ and also by adoption of them for the new compounds. Preparative layer chromatography (PLC) was carried out on $20 \times 20 \mathrm{~cm}^{2}$ plates, coated with $1 \mathrm{~mm}$ layer of Merck silica gel $\mathrm{PF}_{25}$, prepared by applying the silica as a slurry and drying in air.

All irradiations were carried out in a $25 \mathrm{~mL}$ pyrex cell using a $400 \mathrm{~W}$ high pressure $\mathrm{Hg}$ vapor lamp from NARVA and cooling of sample by running water. The light has been passed through a filter solution containing $75 \mathrm{~g} \cdot \mathrm{L}^{-1}$ of $\mathrm{NaNO}_{2}$ and $4.4 \mathrm{~g} \cdot \mathrm{L}^{-1}$ of $\mathrm{CuSO}_{4}$ in $2.7 \mathrm{M} \mathrm{NH}_{4} \mathrm{OH}$ to obtain $\lambda$ $\geq 400 \mathrm{~nm}$ for the selective excitation of the photocatalyst $\mathrm{TP}^{+} \mathrm{BF}_{4}^{-}$and also to prevent the absorption of the light by the sulfides 1a-m and 4.

General procedure for the irradiation of sulfides in the presence of $\mathbf{T P}^{+} \mathbf{B F}_{4}^{-}$. A solution of $1 \mathrm{mmol}$ of sulfides and $0.05 \mathrm{mmol}$ of 2,4,6-triphenylpyrilium tetrafluoroborate $\left(\mathrm{TP}^{+} \mathrm{BF}_{4}^{-}\right)$in $20 \mathrm{~mL}$ oxygenated acetonitrile was irradiated for the time given in Table 1 until total disappearance of sulfides had been observed. After completion of the reaction, solvent was evaporated under reduced pressure and the products were isolated by PLC using n-hexane/ethyl acetate $(7: 2, v / v)$ as eluent.

Physical and spectral data of sulfoxides are as follows:

Benzyl phenyl sulfoxide 2a: m.p. $122-123^{\circ} \mathrm{C}$, m.p. ${ }^{44} 122-$ $124^{\circ} \mathrm{C}$. IR (KBr): $1034 \mathrm{~cm}^{-1} .{ }^{1} \mathrm{H}$ NMR $\left(\mathrm{CDCl}_{3}, 500 \mathrm{MHz}\right)$ : $4.04(\mathrm{~d}, 1 \mathrm{H}, J=12.6 \mathrm{~Hz}), 4.14(\mathrm{~d}, 1 \mathrm{H}, J=12.6 \mathrm{~Hz}$ ), 7.02$7.03(\mathrm{~m}, 2 \mathrm{H}), 7.28-7.36(\mathrm{~m}, 3 \mathrm{H}), 7.41-7.52$ ppm $(\mathrm{m}, 5 \mathrm{H})$.

4-Bromobenzyl phenyl sulfoxide $2 \mathrm{~b}:$ m.p. $178-179^{\circ} \mathrm{C}$, m.p. ${ }^{45} 179^{\circ} \mathrm{C}$. IR (KBr): $1029 \mathrm{~cm}^{-1} .{ }^{1} \mathrm{H} \mathrm{NMR}\left(\mathrm{CDCl}_{3}, 200\right.$ $\mathrm{MHz}): 3.98$ (d, $1 \mathrm{H}, J=12.8 \mathrm{~Hz}), 4.05$ (d, $1 \mathrm{H}, J=12.8 \mathrm{~Hz}$ ), $6.86(\mathrm{~d}, 2 \mathrm{H}, J=8.3 \mathrm{~Hz}), 7.31-7.51 \mathrm{ppm}(\mathrm{m}, 7 \mathrm{H})$.

4-Methylbenzyl Phenyl Sulfoxide 2e: m.p: $97-99^{\circ} \mathrm{C}$, m.p. ${ }^{46} 99-100^{\circ} \mathrm{C}$. IR (KBr): $1027 \mathrm{~cm}^{-1}$. 'H NMR (CDCl $500 \mathrm{MHz}): 2.36(\mathrm{~s}, 3 \mathrm{H}), 3.99(\mathrm{~d}, 1 \mathrm{H}, J=12.6 \mathrm{~Hz}), 4.10(\mathrm{~d}$, $1 \mathrm{H}, J=12.6 \mathrm{~Hz}), 6.91(\mathrm{~d}, 2 \mathrm{H}, J=7.70 \mathrm{~Hz}), 7.10(\mathrm{~d}, 2 \mathrm{H}, J$ $=7.70 \mathrm{~Hz}), 7.42-7.51(\mathrm{~m}, 5 \mathrm{H})$.

4-Nitrobenzyl Phenyl Sulfoxide 2d: m.p: $161-163^{\circ} \mathrm{C}$.

IR (KBr): $1026,1345,1515 \mathrm{~cm}^{-1} .{ }^{1} \mathrm{H}$ NMR ( $\mathrm{CDCl}_{3}, 200$ $\mathrm{MHz}): 4.04$ (d, $1 \mathrm{H}, J=12.0 \mathrm{~Hz}), 4.24(\mathrm{~d}, 1 \mathrm{H}, J=12.0 \mathrm{~Hz}$ ), $7.13(\mathrm{~d}, 2 \mathrm{H}, J=6.5 \mathrm{~Hz}), 7.40-7.51(\mathrm{~m}, 5 \mathrm{H}), 8.12(\mathrm{~d}, 2 \mathrm{H}, J$ $=6.5 \mathrm{~Hz}$ ). Analysis Calcd. for $\mathrm{C}_{13} \mathrm{H}_{11} \mathrm{NSO}_{3}: \mathrm{C}, 59.76 ; \mathrm{H}$, $4.24 ; \mathrm{N}, 5.36 ; \mathrm{S}, 12.27$. Found: C, 59.3; H, 4.4; N, 5.1.

Benzyl 4-methylphenyl sulfoxide $2 \mathrm{e}$ : m.p. $121-123^{\circ} \mathrm{C}$, m.p. ${ }^{46} 122-124^{\circ} \mathrm{C}$. IR (KBr): $1024 \mathrm{~cm}^{-1}$. ${ }^{1} \mathrm{H} \mathrm{NMR}\left(\mathrm{CDCl}_{3}\right.$, $200 \mathrm{MHz}): 2.40(\mathrm{~s}, 3 \mathrm{H}), 4.0(\mathrm{~d}, 1 \mathrm{H}, J=12.5 \mathrm{~Hz}), 4.10(\mathrm{~d}, 1$ $\mathrm{H}, J=12.5 \mathrm{~Hz}), 7.01-7.05(\mathrm{~m}, 2 \mathrm{H}), 7.28-7.32 \mathrm{ppm}(\mathrm{m}, 7 \mathrm{H})$.

4-Bromobenzyl 4-methylphenyl sulfoxide 2f: m.p. 159$161{ }^{\circ} \mathrm{C}$, m.p..$^{47} 161{ }^{\circ} \mathrm{C}$. IR (KBr): $1030 \mathrm{~cm}^{-1}$. 'H NMR $\left(\mathrm{CDCl}_{3}, 500 \mathrm{MHz}\right): 2.46(\mathrm{~s}, 3 \mathrm{H}), 3.99(\mathrm{~s}, 2 \mathrm{H}), 6.88(\mathrm{~d}, 2 \mathrm{H}$,
$J=8.2 \mathrm{~Hz}), 7.27-7.31(\mathrm{~m}, 4 \mathrm{H}), 7.42 \mathrm{ppm}(\mathrm{d}, 2 \mathrm{H}, J=8.2$ $\mathrm{Hz}$ ).

Benzyl 4-chlorophenyl sulfoxide $2 \mathrm{~g}$ : m.p. $120-122^{\circ} \mathrm{C}$, m.p. $\left.{ }^{+6} 120-122^{\circ} \mathrm{C}\right)$. IR (KBr): $1036 \mathrm{~cm}^{-1} .{ }^{1} \mathrm{H} \mathrm{NMR}\left(\mathrm{CDCl}_{3}\right.$, $200 \mathrm{MHz}): 4.02$ (d, $1 \mathrm{H}, J=12.5 \mathrm{~Hz}), 4.15$ (d, $1 \mathrm{H}, J=12.5$ $\mathrm{Hz}), 7.02(\mathrm{~d}, 2 \mathrm{H}, J=6.8 \mathrm{~Hz}), 7.26-7.46(\mathrm{~m}, 5 \mathrm{H}), 7.36 \mathrm{ppm}$ (d, $2 \mathrm{H}, J=6.8 \mathrm{~Hz}$ ).

4-Bromobenzyl 4-chlorophenyl sulfoxide $2 \mathrm{~h}: \mathrm{m} . \mathrm{p}$. 134$136^{\circ} \mathrm{C}$, m.p. ${ }^{+5} 135-136^{\circ} \mathrm{C}$. IR (KBr): $1037 \mathrm{~cm}^{-1} .{ }^{1} \mathrm{H}$ NMR $\left(\mathrm{CDCl}_{3}, 200 \mathrm{MHz}\right): 3.98$ (d, $\left.1 \mathrm{H}, J=12.85 \mathrm{~Hz}\right), 4.05$ (d, $1 \mathrm{H}$, $J=12.85 \mathrm{~Hz}$ ), 6.87 (d, $2 \mathrm{H}, J=8.40 \mathrm{~Hz}), 7.30$ (d, $2 \mathrm{H}, J=$ $8.40 \mathrm{~Hz}), 7.45-7.51 \mathrm{ppm}(\mathrm{m}, 4 \mathrm{H})$.

4-Chlorophenyl 4-nitrobenzyl sulfoxide $2 \mathrm{i}$ : m.p. 154$155^{\circ} \mathrm{C}$, m.p. ${ }^{47} 153.5-154.5^{\circ} \mathrm{C}$. IR (KBr): $1040,1345,1515$ $\mathrm{cm}^{-1}$. 'H NMR ( $\left.\mathrm{CDCl}_{3}, 500 \mathrm{MHz}\right): \delta=4.04$ (d, $1 \mathrm{H}, J=$ $12.83 \mathrm{~Hz}$ ), 4.24 (d, $1 \mathrm{H}, J=12.83 \mathrm{~Hz}), 7.17$ (d, $2 \mathrm{H}, J=8.53$ $\mathrm{Hz}$ ), 7.33 (d, $2 \mathrm{H}, J=8.53 \mathrm{~Hz}), 7.48$ (d, $2 \mathrm{H}, J=8.53 \mathrm{~Hz}$ ), 8.17 ppm (d, $2 \mathrm{H}, J=8.53 \mathrm{~Hz}$ ).

Benzyl 4-bromobenzyl sulfoxide $2 \mathrm{j}$ : m.p. $139-140^{\circ} \mathrm{C}$. IR (KBr): $1028 \mathrm{~cm}^{-1}$. ${ }^{1} \mathrm{H}$ NMR $\left(\mathrm{CDCl}_{3}, 500 \mathrm{MHz}\right): 3.78$ (d, 1 $\mathrm{H}, J=13.09 \mathrm{~Hz}$ ), 3.89 (d, $1 \mathrm{H}, J=13.09 \mathrm{~Hz}$ ), 3.95 (s. $2 \mathrm{H}$ ), $7.2(\mathrm{~d}, 2 \mathrm{H}, J=8.27 \mathrm{~Hz}), 7.32-7.33(\mathrm{~m}, 2 \mathrm{H}), 7.40-7.44(\mathrm{~m}, 3$ H), 7.54 ppm (d, $2 \mathrm{H}, J=8.27 \mathrm{~Hz}$ ). Analysis Calcd. for $\mathrm{C}_{14} \mathrm{H}_{13} \mathrm{SOBr}$ C, 54.38; H, 4.24. Found: C, 54.0; H, 4.3.

Dibenzyl sulfoxide $2 \mathrm{k}$ : m.p. $131-133^{\circ} \mathrm{C}$, m.p. ${ }^{48} 132-134$ ${ }^{\circ} \mathrm{C}$. IR (KBr): $1026 \mathrm{~cm}^{-1}$. 'H NMR (CDCl, $\left.500 \mathrm{MHz}\right): 3.91$ (d, $2 \mathrm{H}, J=13.0 \mathrm{~Hz}), 3.98(\mathrm{~d}, 2 \mathrm{H}, J=13.0 \mathrm{~Hz}), 7.31-7.41$ ppm $(\mathrm{m}, 10 \mathrm{H})$.

Diphenyl sulfoxide 2l: m.p. $70-72^{\circ} \mathrm{C}, \mathrm{m} . \mathrm{p} .^{+8} 69-72^{\circ} \mathrm{C} . \mathrm{IR}$ (KBr): $1038 \mathrm{~cm}^{-1}$. 'H NMR ( $\left.\mathrm{CDCl}_{3}, 200 \mathrm{MHz}\right): 7.41-7.50$ $(\mathrm{m}, 6 \mathrm{H}), 7.61-7.66$ ppm $(\mathrm{m}, 4 \mathrm{H})$.

Dibenzothiophene sulfoxide $5:$ m.p. $181-183^{\circ} \mathrm{C}$, m.p. ${ }^{49}$ $181-183^{\circ} \mathrm{C}$. IR (KBr): $1038 \mathrm{~cm}^{-1} .{ }^{1} \mathrm{H}$ NMR $\left(\mathrm{CDCl}_{3}, 500\right.$ $\mathrm{MHz}): 7.53-7.70(\mathrm{~m}, 4 \mathrm{H}), 7.83-8.04 \mathrm{ppm}(\mathrm{m}, 4 \mathrm{H})$.

Acknowledgements. We are thankful to the Office of Graduate Studies of the University of Isfahan for their financial support.

\section{References}

I. Sinnreich, D.; Lind, H.; Batzer, H. Tetrahedron Lett. 1976, 3541.

2. Tezuka, T.; Miyazaki, H.; Suzuki, H. Tetrahedron Letf. 1978, 1959.

3. Akasaka, T.; Yabe, A.; Ando, W. J. An. Chent. Soc. 1987, 109 . 8085.

4. Vialaton, D.; Richard, C. J. Photochem. Photobiol, A: Chem. $2000,136,169$.

5. Davidson, R. S.; Goodin, J. W.; Pratt, J. E. Tetrahedron Lett. 1982. 23,2225 .

6. Davidson, R. S.; Partt, J. E. Tetrahedron Lett. 1983, 24, 5903.

7. Kamala, M.; Salo, M.; Hasegawa, E. Tetrahedron Lett. 1992, 33 , 5085.

8. Baciocchi, E.; Del Giacco, T.; Ferrero, M. I.; Rol, C.; Sebastiani, G. V. J. Org. Chent 1997, 62, 4015.

9. Baciocchi, E.; Crescenzi, C.; Lanzalunga, O. Tetrahedron 1997. $53,4469$.

10. Shiraishi, Y.; Taki, Y.; Hirai, T.; Komasawa, I. Chem. Commun. 1998,2601

11. Soggiu, N.; Cardy, H.; Habib Jiwan, J. L.; Leray, I.; Soumillion, J. 
Ph.; Lacombe, S. J. Photochem. Photobiol. A: Chent 1999, 124, 1.

12. Baciocchi, E.; Giacco, T. D.; Elisei, F.; Gerini, M. F.; Guerra, M.; Lapi, A.; Liberali, P. J. Am. Chem. Soc. 2003, /25, 16444.

13. Foote, C. S.; Peters, J. W. J. Am. Chem. Soc. 1971, 93, 3795.

14. Ando, W.; Nagashima, T.; Saito, K.; Kohmoto, S. J. Chem. Soc. Chem. Commun. 1979, 154.

15. Sawaki, Y.; Ogata, Y.J. Am. Chem. Soc. 1981, 103,5947.

16. Gu, C.-L.; Foote, C. S.; Kacher, M. L. J. Am. Chem. Soc. 1981 , 10,5949 .

17. Bhalerao, U. T.; Sridhar, M. Tetrahedron Lett. 1994, 35, 1413.

18. Jensen, F.; Greer, A.; Clennan, E. L. J. Am. Chem. Soc. 1998, I20, 4439.

19. Bonesi, S. M.; Albini, A. J. Org. Chem. 2000, 65, 4532.

20. Lacombe, S.; Cardy, H.; Simon, M.: Khoukh, A.; Soumillion, J. Ph.; Avadim, M. Photochem. Photobiol. Sci. 2002, 1, 347.

21. Madhavan, D.; Pitchumani, K. Tetrahedron 2001, 57, 8391 .

22. Bonesi, S. M.; Fagoni, M.; Monti, S.; Albini, A. Photochem. Photobiol. Sci. 2004, 3, 489 .

23. Mattes, S. L.; Farid, S. J. Ami. Chem. Soc. 1986, J08, 7356.

24. Ericksen, J.; Foote, C. S.; Parker, T. L. J. An. Chem. Soc. 1977, 09,6455 .

25. Galindo, F.; Mitanda, M. A. J. Photochem, Photobiol. A: Chem. $1998,1 / 3,155$

26. Zhang, W, Jia, X.; Yang, L.; Liu, Z.-L. Tetrahedron Lett, 2002, 43,9433.

27. Wong, P. C.; Arnold, D. R. Tetrahedron Lett. 1979, 23, 2101.

28. Shima, K.; Sazaki, A.; Nakabayashi, K.; Yasuda, M. Bull. Chen. Soc. Jpn. 1992, 65, 1472.

29. Memarian, H. R,; Hessami, A.; Nikpour, F; Dopp, D. Indian J. Chem. 2001, 4OB, 662

30. Memarian, H. R.; Nikpour, F. Chem. Mon. 2002, 133, 1045.
31. Memarian, H. R; Nikpour, F, Molectles 2002, 7, 63.

32. Memarian, H. R.; Nikpour, F. J. Chin. Chem. Soce 2002, 49. 401 .

33. No reaction has been observed on irradiation of a-epoxyketones in the presence of $\mathrm{TiO}_{2}$.

34. Memarian, H. R.; Sabzyan, H.; Nikpour, F. Photoinduced electron transfer ring opening of $\alpha$-epoxyketones using 7,7,8,8-tetracyano$p$-quinodimethane (TCNQ), manuscript in preparation.

35. Corey, E. J.; Ouanennes, C. Tetrahedron Lett. 1976, 4263.

36. Toulchkine, A.; Clennan, E. L. J. Am. Chem, Soc. 2000, 122, 1834.

37. Akaba, R.; Aihars, S.; Sakuragi, H.; Tokumaru, K. J. Chem. Soc. Chen. Conmum. 1987, 1262.

38. Akaba, R.; Sakuragi, H.; Tokumaru, K. J. Chem. Soc Perkin Trans. 2 1991. 291.

39. Purdie, J. W. Can. J. Chem, 1971, 49, 725.

40. Oae, S.; Takata, T.; Kim, Y. H. Tetrahedron 1981, 37, 37.

4l. Miranda, M. A.; Garcia, H. Chem. Rev, 1994, 94, 1063.

42. Vogel's Textbook of Proctical Organic Chenistry; 5th ed.; Longmann Scientific \& Technical: Essex, 1989; p 789.

43. Hafner, K.; Kaiser, H. Organic Synthesis; Wiley: New York, 1973; Coll. Vol. 5, p 1088.

44. Ali, M. H.; Leach, D. R.; Schmitz, C. E. Sywth. Commun. 1998, 28,2969 .

45. Clark, N. G.; Cranham, J. E.; Greenwood, D.; Marshall, J. R.; Stevenson, H. A.J. Sci. Food Agric. 1957, 8, 566.

46. Choudary, B. M.; Bharathi, B.; Venkat Reddy, Ch.; Lakshmi Kantam. M. J. Chem. Soc., Perkin Trans. I 2002. 2069.

47. Brookes, R. F.; Clark, N. G.; Cranham, J. E.; Greenwood, D.; Marshall, J. R.; Stevenson, H. A. J. Sci. Food Agric. 1958, 9, I11. 48. Drabowicz, J.; Midura, W.; Mikolajczyk, M. Synthesis 1979, 39. 49. Watanabe, Y.; Numata, T.; Oae, S. Sythes is 1981. 204. 